\title{
Plasticity in carbon acquisition of the heterophyllous Luronium natans: An endangered freshwater species in Europe
}

\author{
Benita Hyldgaard*, Hans Brix \\ Plant Biology, Department of Biological Sciences, Aarhus University, Denmark
}

\section{A R T I C L E I N F O}

\section{Article history:}

Received 16 April 2010

Received in revised form

23 December 2010

Accepted 13 January 2011

Available online 20 January 2011

\section{Keywords:}

Amphibious

Floating Water-plantain

Inorganic carbon

Macrophyte

Photosynthesis

Rubisco

\begin{abstract}
A B S T R A C T
Luronium natans (L.) Raf. (Floating Water-plantain) is an endangered amphibious freshwater species endemic to Europe. We examined the plasticity in carbon acquisition and photosynthesis in $L$. natans to assess if lack of plasticity could contribute to explain the low competitive ability of the species. The plasticity of photosynthesis in submerged leaves towards inorganic carbon availability was examined and the photosynthesis of submerged, floating and aerial leaves was contrasted. L. natans was shown to be plastic in inorganic carbon uptake, as it was able to effectively acclimate to changed concentrations of free- $\mathrm{CO}_{2}$. The photosynthetic apparatus was down-regulated in plants grown at high $\mathrm{CO}_{2}$. Chlorophyll concentration, Rubisco activity and maximum photosynthesis were significantly lower in submerged leaves of plants grown at high $\mathrm{CO}_{2}\left(200 \mu \mathrm{M}\right.$ free- $\left.\mathrm{CO}_{2}\right)$ compared to plants grown at low $\mathrm{CO}_{2}(18 \mu \mathrm{M}$ free- $\mathrm{CO}_{2}$ ). Furthermore, bicarbonate utilization was down-regulated in response to high $\mathrm{CO}_{2}$. Carbon acquisition of submerged, floating and aerial leaves of L. natans differed significantly. The aerial leaves were superior in photosynthesising in air and, surprisingly, the floating leaves had the highest rates of photosynthesis in water. The study did not support the hypothesis that the low competitive ability of L. natans is caused by inefficient photosynthesis or a lack of plasticity in photosynthesis. However, the somewhat low photosynthetic performance of the submerged leaves may be a contributing factor.
\end{abstract}

(c) 2011 Elsevier B.V. All rights reserved.

\section{Introduction}

The amphibious freshwater species, Luronium natans (L.) Raf. (Floating Water-plantain) is endangered and the populations are declining in most parts of its distribution area. The species is endemic to Europe and can be found in a great range of environments including eutrophic rivers in France (Greulich et al., 2000b), oligotrophic softwater as well as calcareous lakes in Britain (Willby and Eaton, 1993) and eutrophic, disturbed man-made canals in Denmark (Nielsen et al., 2006b). One of the extraordinary features of $L$. natans is its ability to grow both fully submerged in the form of a bottom-dwelling rosette, as a nymphaeid with floating leaves, and completely emerged as a small terrestrial, however sterile, plant (Greulich et al., 2001).

Several experiments have been performed to explore the ecology of $L$. natans in an attempt to explain the rarity of this species. A transplant experiment in the Rhone district of France did not support the hypothesis of environmental conditions being restrictive for the distribution of $L$. natans as clear correlations between

\footnotetext{
* Corresponding author at: Plant Biology, Department of Biological Sciences, Aarhus University, Ole Worms Allé 1, Building 1135, 8000 Aarhus C, Denmark. Tel.: +458942 4715; fax: +458942 4747 .

E-mail address: benita.hyldgaard@biology.au.dk (B. Hyldgaard).
}

failure/success sites and the abiotic characteristics of sediment and water were not revealed (Greulich et al., 2000a). When transplanted from its natural habitat to a new locality, L. natans established well and expanded by vigorous vegetative spreading via runners (Greulich et al., 2000a). Also it was highly plastic in morphology, as it shifted growth form from isoetid to nymphaeid (Greulich et al., 2001). The overall ability of L. natans to compete with other plant species seems, however, to be low (Greulich and Bornette, 1999). L. natans appears to be favoured by fluctuating water levels and physical disturbance, such as regular sediment dredging and weed cutting in managed streams and canals (Nielsen et al., 2006a). Physical disturbance and weed cutting restrict the growth and competition from other species in the community and seem to stimulate growth of $L$. natans. Sexual reproduction seems, however, to be efficient, as $L$. natans has a high production of seeds that readily germinate (Nielsen et al., 2006b). Vegetative spreading via runners also seems to be efficient.

Plants, as sessile organisms, constantly need to acclimate to the prevailing conditions. The extent of plasticity in phenotype determines the width of environmental conditions in which a plant can maintain unaltered fitness (Sultan, 2000). Phenotypic plasticity has been defined as the property of a genotype to express distinct phenotypes when exposed to different environments (Richards et al., 2006). Lack of adequate plasticity in photosynthesis may be a contributing factor to the low competitive capacity of the hetero- 
phyllous L. natans, as high plasticity is crucial for producing leaves that are efficient in photosynthesising both in air and in water. The transition from photosynthesising under water to aerial photosynthesis demands several alterations. One of the major differences between the two media is the large negative water potential in air, which necessitates production of barriers to water loss in aerial leaves such as a thick cuticle to prevent desiccation and stomata to secure $\mathrm{CO}_{2}$ uptake (Maberly and Spence, 1989). In submerged leaves, presence of a thick cuticle would severely impede the flux of gasses through the leaf surface, constraining the uptake of inorganic carbon. Photosynthesis under water is often limited by inorganic carbon availability, notably for $\mathrm{CO}_{2}$ users (Maberly and Spence, 1989 ) because of the slow diffusion of gasses in water. Production of aerial leaves enables amphibious plants to overcome the demand for carbon, as $\mathrm{CO}_{2}$ is more readily taken up from the air. However, to photosynthesise efficiently, several parts of the photosynthetic apparatus need to be readjusted after emergence, requiring high phenotypic plasticity. Another strategy to alleviate the carbon limitation in water is found in some aquatic plant species that have developed an ability to exploit bicarbonate ions $\left(\mathrm{HCO}_{3}{ }^{-}\right)$in addition to free- $\mathrm{CO}_{2}$ (Prins and Elzenga, 1989). Bicarbonate utilization is an energetically costly carbon-concentrating mechanism (Madsen and Sand-Jensen, 1991), and thus disadvantageous and superfluous at high free- $\mathrm{CO}_{2}$ concentrations. Several studies have shown freshwater plants to be plastic in this trait, by suppressing the bicarbonate affinity when growing at high concentrations of free- $\mathrm{CO}_{2}$ (e.g. Sand-Jensen and Gordon, 1986; Madsen et al., 1996). Plasticity in carbon acquisition strategies is important for aquatic plants as the supply of the different forms of inorganic carbon is highly variable, both spatially and temporally, in freshwater systems (Van et al., 1976).

The overall aim of this study was to assess if lack of plasticity in carbon acquisition and photosynthesis may be a contributing factor to the low competitive capacity of the endangered L. natans. We therefore examined the plasticity in the photosynthetic carbon assimilation of submerged leaves of $L$. natans towards inorganic carbon availability in the water. We also contrasted photosynthesis of submerged, floating and aerial leaves in both water and air, and assessed the capacity of the leaves to utilize bicarbonate as an inorganic carbon source. We hypothesised that the low competitive ability of $L$. natans is caused, in part, by a low level of phenotypic plasticity in carbon acquisition. This would be seen as an inability to effectively adjust photosynthetic carbon uptake in the different leaf types to the prevailing environmental conditions, and for the submerged leaves to have a low plasticity in response to inorganic carbon availability.

\section{Materials and methods}

\subsection{Plant material}

Submerged specimina of $L$. natans were collected in January and October 2008 from populations in Kimmelkær Canal $\left(56^{\circ} 11^{\prime} 16 \mathrm{~N}\right.$, $8^{\circ} 14^{\prime} 08 \mathrm{E}$ ), a slowly flowing tidally influenced drainage canal located close to the west coast of Denmark. The water quality in the canal is very variable because of the tidal influence and the seasonal variation in drainage water quality and quantity. However, in a nearby river, the mean ( \pm 1 S.D.) alkalinity was $0.51 \pm 0.11 \mathrm{meq} \mathrm{L} \mathrm{L}^{-1}$ and $\mathrm{pH} 6.97 \pm 0.26$ corresponding to a mean concentration of free$\mathrm{CO}_{2}$ of $130 \pm 69 \mu \mathrm{M}$ (Rebsdorf et al., 1991). The plants were rinsed carefully in tap-water and thereafter placed in 15-L aquaria containing a standard $\mathrm{N}$ and $\mathrm{P}$-free culture medium with an alkalinity of $0.85 \mathrm{meq} \mathrm{L}^{-1}$ prepared according to Smart and Barko (1985). A commercial plant nutrition liquid for aquarium plants containing all essential macro and micronutrients (Tropica ${ }^{\circledR}$ Aquacare Plant
Nutrition+, Tropica Aquarium Plants, Egaa, DK) was added to the culture medium to reach concentrations of $\mathrm{N}$ and $\mathrm{P}$ of 99.5 and $3.4 \mu \mathrm{M}$, respectively. The aquaria were continuously aerated with atmospheric air and placed in a $15^{\circ} \mathrm{C}$ growth chamber at a photon flux density of $130 \mu \mathrm{mol} \mathrm{m}^{-2} \mathrm{~s}^{-1}$ PAR (photosynthetically active radiation) at the water surface provided by metal halide bulbs in a $14 \mathrm{~h}$ light $/ 10 \mathrm{~h}$ dark cycle until initiation of the experiments.

Plants with aerial leaves were produced by planting submerged shoots in 0.4-L pots with sphagnum peat and 8-10 slow-release fertiliser pellets (Osmocote Plus, Pindstrup Mosebrug A/S, DK). The pots were placed in an aquarium with tap-water at $19^{\circ} \mathrm{C}( \pm 0.5)$ and 60-70 $\mu \mathrm{mol} \mathrm{m}^{-2} \mathrm{~s}^{-1}$ (PAR) at the soil surface. Initially, the water level was kept $10 \mathrm{~mm}$ above soil surface and then gradually lowered to $50 \mathrm{~mm}$ below soil surface as aerial leaves developed.

\subsection{Experiments}

\subsubsection{Experiment 1: acclimation potential of submerged leaves to different $\mathrm{CO}_{2}$ concentrations}

Plants with submerged leaves $(n=18-20)$ were grown at ambient $(18 \mu \mathrm{M})$ and high $(200 \mu \mathrm{M})$ free- $\mathrm{CO}_{2}$ levels in the water to assess the plasticity in carbon uptake of submerged leaves. One week after collection in January 2008, plants were mounted in an up-right position in plastic nets and grown in two replicate aquaria with the standard culture medium and at light, temperature and nutrient conditions as described above.

The $\mathrm{CO}_{2}$ concentrations in the water were controlled by continuous bubbling by atmospheric air to maintain ambient $\mathrm{CO}_{2}$ concentrations, or by atmospheric air enriched with pure $\mathrm{CO}_{2}$ from a pressurised gas cylinder to maintain a concentration of $200 \mu \mathrm{M}$ free- $\mathrm{CO}_{2}$ in the water. The water was renewed every week to prevent significant development of algae, and any filamentous algae on the plants were gently removed with a fine brush as necessary. After three weeks of growth at low and high $\mathrm{CO}_{2}$ concentrations, the response of the rate of photosynthesis to $\mathrm{CO}_{2}$ availability $\left(\mathrm{CO}_{2}\right.$ response curves), and the ability of the plants to utilize $\mathrm{HCO}_{3}{ }^{-}(\mathrm{pH}$ drift experiments) were studied using the methodologies described below.

\subsubsection{Experiment 2: inorganic carbon assimilation by different leaf types}

The inorganic carbon uptake characteristics of the submerged and floating leaves of $L$. natans were studied using plants collected in October 2008. The plants were rinsed and placed in two 15$\mathrm{L}$ aerated aquaria containing two third water from the sampling locality and one third standard culture medium with an alkalinity of $0.85 \mathrm{meq} \mathrm{L}^{-1}$ (Smart and Barko, 1985). No additional nutrients were added. The aquaria were placed at $15^{\circ} \mathrm{C}$ and a light intensity of $130 \mu \mathrm{mol} \mathrm{m}^{-2} \mathrm{~s}^{-1}$ (PAR) at the water surface supplied in a $14 \mathrm{~h}$ light $/ 10 \mathrm{~h}$ dark cycle. Measurements of inorganic carbon assimilation were carried out as soon as possible and completed within nine days after collection to minimise acclimation to laboratory conditions.

\section{3. $\mathrm{CO}_{2}$ response curves}

\subsubsection{Experiment 1}

The response of the light-saturated rate of photosynthesis to $\mathrm{CO}_{2}$ availability was measured as oxygen evolution at different concentrations of free- $\mathrm{CO}_{2}$ in the medium. A single submerged leaf was incubated in a Perspex chamber equipped with a Clarktype oxygen electrode and containing $5.5 \mathrm{~mL}$ MES buffer $(20 \mathrm{mM}$ 2-[N-morpholino]ethanesulfonic acid) adjusted to $\mathrm{pH} 5.5$. The MES buffer was prepared from milli-Q water containing $0.28 \mathrm{mM}$ $\mathrm{MgSO}_{4}$ and $0.62 \mathrm{mM} \mathrm{CaCl}_{2}$; the same concentrations as in the standard culture medium. The medium in the temperature-controlled 
$\left(15 \pm 0.1^{\circ} \mathrm{C}\right)$ incubation chamber was stirred continuously by a magnetic stirrer and purged with $\mathrm{N}_{2}$ gas prior to measurements to reduce the oxygen concentration to approximately $70 \%$ saturation. A saturating irradiance of $300 \mu \mathrm{mol} \mathrm{m}^{-2} \mathrm{~s}^{-1}$ (PAR) was provided by a $24 \mathrm{~V}$ metal halide projector lamp. The rate of photosynthesis was measured at ten free- $\mathrm{CO}_{2}$ concentrations between 0 and $800 \mu \mathrm{M}$, which were obtained by spiking with $\mathrm{KHCO}_{3}$ from a stock solution. At pH 5.5, 88\% of total inorganic carbon is in the form of free- $\mathrm{CO}_{2}$ at $15^{\circ} \mathrm{C}$. The actual concentration of total inorganic carbon in the medium was analysed by injecting $100 \mu \mathrm{L}$ of medium into a glass Büchner funnel containing $5 \% \mathrm{HNO}_{3}$. Gaseous $\mathrm{N}_{2}$ was purged through the funnel from below and the resulting gas was led via gas-tight tubing to an infrared gas analyser (IRGA, LI-820 $\mathrm{CO}_{2}$ Gas analyser, LI-COR Inc., NE, USA) connected to an integrator for analysis of the $\mathrm{CO}_{2}$ released from the sample.

\subsubsection{Experiment 2}

$\mathrm{CO}_{2}$ response curves were made for submerged, floating and aerial leaves in both air and water as described below.

2.3.2.1. Photosynthesis in air. The day after collection of the plants, photosynthesis in air was measured at different $\mathrm{CO}_{2}$ concentrations in the surrounding air using a portable photosynthesis system (IRGA, LI-6400XT, LI-COR Inc., NE, USA) with a leaf chamber equipped with a 6400-01 $\mathrm{CO}_{2}$ Injector System. Light was supplied by a 6400-02B LED Light Source supplying a saturating irradiance of $800 \mu \mathrm{mol} \mathrm{m}^{-2} \mathrm{~s}^{-1}$ (PAR). The part of the plant not clamped into the leaf chamber was covered with moist tissue paper to reduce desiccation, and the incoming air was water-saturated before entering the chamber. Measurements on individual leaves were performed at $15^{\circ} \mathrm{C}$ at the following set point $\mathrm{CO}_{2}$ concentrations and sequence: $400,250,150,0,400,400,600$ and $800 \mu \mathrm{mol} \mathrm{mol}^{-1}$. After reaching each $\mathrm{CO}_{2}$ concentration, the plant was left to stabilise for at least $60 \mathrm{~s}$ before the reading was logged.

2.3.2.2. Photosynthesis in water. Photosynthesis of leaves in water was measured as $\mathrm{O}_{2}$ evolution at different external free- $\mathrm{CO}_{2}$ concentrations in the standard culture medium (Smart and Barko, $1985)$ under stirred conditions at $15^{\circ} \mathrm{C}$. Excised leaves $(n=3-5)$ were incubated in a 52.7-mL Perspex chamber with a lid with holes fitted for a combination pH-electrode (PHC2001-8, PHM 92 LAB pH meter, MeterLab ${ }^{\mathrm{TM}}$, Radiometer Analytical A/S, DK) and a Clarktype oxygen microsensor (Type OX-500, Unisense A/S, DK). The chamber was placed in a temperature controlled water bath, and a saturating irradiance of $450 \mu \mathrm{mol} \mathrm{m}^{-2} \mathrm{~s}^{-1}$ (PAR) was provided from a $24 \mathrm{~V}$ metal halide projector lamp. Initially, the medium was purged with $\mathrm{N}_{2}$ gas to lower initial $\mathrm{O}_{2}$ concentration to approximately $70 \%$ saturation. Free- $\mathrm{CO}_{2}$ concentrations were controlled by manipulating the solution $\mathrm{pH}$ by addition of aliquots of $0.1 \mathrm{M}$ $\mathrm{HCl}$ and $\mathrm{NaOH}$ to the incubation chamber. Measurements were made at approximately $0.5 \mathrm{pH}$ unit intervals between $\mathrm{pH} 5.5$ and 7.5 , and at $\mathrm{pH} 8.5$ and 10.0 to cover free- $\mathrm{CO}_{2}$ concentrations from approximately $700 \mu \mathrm{M}$ to $<0.1 \mu \mathrm{M}$. Oxygen concentration and $\mathrm{pH}$ were recorded continuously, and stable photosynthesis rates were obtained before the $\mathrm{pH}$ was manipulated to reach the next $\mathrm{CO}_{2}$ level. Total inorganic carbon and free- $\mathrm{CO}_{2}$ concentrations were determined from alkalinity and $\mathrm{pH}$, and corrected for carbon uptake by the plant during the experiment. After measurements, the leaves were weighed (fresh weight), photocopied and then frozen for later chlorophyll extraction and dry weight determination. Leaf area was calculated from the weight:area-ratio of the photocopies.

\section{4. $p H$ drift experiment}

The ability of the different leaf types to utilize bicarbonate $\left(\mathrm{HCO}_{3}{ }^{-}\right)$was assessed by means of simple $\mathrm{pH}$ drift experiments
(Allen and Spence, 1981). Leaf material corresponding to 0.15-0.3 g fresh weight (FW) of the three leaf types $(n=5)$ was gently detached and placed in separate $30-\mathrm{mL}$ glass-stoppered bottles containing the standard culture medium with an alkalinity of 0.85 meq L (Smart and Barko, 1985). The bottles contained a small air bubble during incubations to minimize build-up of oxygen in the water and to secure efficient mixing during incubation. For the acclimation experiment, only submerged leaves were used. Prior to the experiment, the medium was temperature-adjusted to $15^{\circ} \mathrm{C}$ and aerated with atmospheric air to ensure equilibrium with atmospheric $\mathrm{CO}_{2}$ and $\mathrm{O}_{2}$. The bottles were mounted on a rotating wheel in a thermostatic incubator $\left(15^{\circ} \mathrm{C}\right)$ at a photon irradiance of $250 \mu \mathrm{mol} \mathrm{m}{ }^{-2} \mathrm{~s}^{-1}$ (PAR) from fluorescent tubes for $24-48 \mathrm{~h}$. Final $\mathrm{pH}$ was measured using a calibrated combination pH-electrode (PHC2001-8) and alkalinity was analysed by Gran plot titration using a TIM 850 Titration Master (Radiometer Analytical S.A., Villeurbanne CEDEX, France) with $0.01 \mathrm{M} \mathrm{HCl}$. pH drift experiments were carried out the day after collection of plant material for the leaf type comparison experiment (Experiment 2) and at termination of acclimation in the $\mathrm{CO}_{2}$ acclimation experiment (Experiment 1 ).

\subsection{Enzyme analysis}

The activity of Ribulose-1,5-bisphosphate Carboxylase/Oxygenase (Rubisco) was analysed in plant material sampled from both experiments at midday and frozen immediately in liquid nitrogen. The frozen plant material was ground to powder in liquid $\mathrm{N}_{2}$ with a mortar and pestle. Subsequently, a portion of the powder was homogenised using a pre-chilled Ten Broeck homogenisator with $5 \mathrm{~mL}$ ice-cold extraction buffer containing $50 \mathrm{mM} \mathrm{CO}_{2}$-free Bicine (pH 8.0), $10 \mathrm{mM} \mathrm{MgCl}$, $5 \mathrm{mM}$ dithiothreitol (DTT), $10 \mathrm{mM}$ isoascorbate, $0.1 \mathrm{mM}$ ethylenediaminetetraacetic acid (EDTA) and $2 \%(\mathrm{w} / \mathrm{v})$ polyvinyl-pyrrolidone (PVP)-40. Aliquots of the homogenates were taken for chlorophyll determination. Assays were performed at $15^{\circ} \mathrm{C}$ in $6-\mathrm{mL}$ plastic vials containing $300 \mu \mathrm{L}$ assay solution ( $50 \mathrm{mM} \mathrm{CO}$-free Bicine ( $\mathrm{pH} \mathrm{8.0),} 10 \mathrm{mM} \mathrm{MgCl}_{2}$, $5 \mathrm{mM}$ DTT and $0.1 \mathrm{mM}$ EDTA) and $50 \mu \mathrm{L} 192.5 \mathrm{mM} \mathrm{NaH}^{14} \mathrm{CO}_{3}$. Rubisco activity was determined by adding $100 \mu \mathrm{L}$ plant extract and $50 \mu \mathrm{L} 5 \mathrm{mM}$ RuBP (D-Ribulose 1,5-bisphosphate sodium salt hydrate) simultaneously to the assay mixture. The total Rubisco activity was determined by incubating the plant extract in the buffer solution for $5 \mathrm{~min}$ prior to addition of RuBP. The reactions were terminated after $60 \mathrm{~s}$ by addition of $100 \mu \mathrm{L} 6 \mathrm{~N} \mathrm{HCl}$. The samples were dried at $60^{\circ} \mathrm{C}$ for $24 \mathrm{~h}$ and re-dissolved in two drops of $6 \mathrm{M} \mathrm{KOH}, 1.2 \mathrm{~mL}$ milli-Q water and hereafter $3.2 \mathrm{~mL}$ scintillation liquid (Insta-gel Plus, PerkinElmer Life and Analytical Sciences, Shelton, USA) was added. The radioactivity of the bound acid-stable ${ }^{14} \mathrm{C}$ was determined by liquid scintillation counting (Liquid Scintillation Analyzer, Tri-CARB 2100 TR, Packard, USA). Chlorophyll content was determined by spectrometry after overnight extraction in 96\% ethanol (Lichtenthaler, 1987) to enable expression of Rubisco activity on a dry weight basis.

\subsection{Chlorophyll concentration}

Dry weight of the leaves was obtained by freeze-drying to constant weight. Subsequently, contents of total chlorophylls (Chl $a$ and $\mathrm{Chl} b$ ) were determined spectrophotometrically on the freezedried material after extraction overnight in darkness in 96\% ethanol (Lichtenthaler, 1987).

\subsection{Data analysis}

Data were analysed by one-way analysis of variance (ANOVA) using the software Statgraphics Centurion XV (Statpoint Technologies, Inc., Warrenton, VA, USA). For the $\mathrm{CO}_{2}$ acclimation experiment 
Table 1

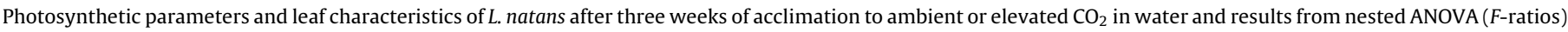

\begin{tabular}{|c|c|c|c|c|c|c|}
\hline & \multirow[t]{2}{*}{ Ambient $\mathrm{CO}_{2}$} & \multirow[t]{2}{*}{ Elevated $\mathrm{CO}_{2}$} & \multicolumn{2}{|c|}{$\mathrm{CO}_{2}$ level } & \multicolumn{2}{|c|}{ Aquaria $\left(\mathrm{CO}_{2}\right.$ level $)$} \\
\hline & & & Df & $F$-ratio & Df & $F$-ratio \\
\hline$P_{\text {growth }}\left(\mu \mathrm{mol} \mathrm{O}_{2} \mathrm{~g}^{-1} \mathrm{DWh}^{-1}\right)$ & $188 \pm 14$ & $141 \pm 29$ & $F_{(1,2)}$ & 5.4 & $F_{(2,16)}$ & 0.88 \\
\hline$P_{\text {sat }}\left(\mu \mathrm{mol} \mathrm{O}_{2} \mathrm{~g}^{-1} \mathrm{DWh}^{-1}\right)$ & $572 \pm 45$ & $229 \pm 45$ & $F_{(1,2)}$ & $130.7^{* *}$ & $F_{(1,16)}$ & 0.22 \\
\hline $\mathrm{Chl}_{a+b}\left(\mathrm{mg} \mathrm{g}^{-1} \mathrm{DW}\right)$ & $7.2 \pm 0.3$ & $3.1 \pm 0.3$ & $F_{(1,2)}$ & $350.6^{* *}$ & $F_{(2,18)}$ & 0.23 \\
\hline DW:FW-ratio & $0.08 \pm 0.01$ & $0.22 \pm 0.01$ & $F_{(1,2)}$ & $166.5^{* *}$ & $F_{(2,16)}$ & 0.57 \\
\hline $\operatorname{Rubisco}_{\text {Non }}\left(\mu \mathrm{molCg}^{-1} \mathrm{DWh}^{-1}\right)$ & $159 \pm 9$ & $69 \pm 9$ & $F_{(1,2)}$ & $20.9^{*}$ & $F_{(2,15)}$ & 2.79 \\
\hline 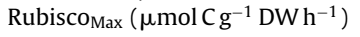 & $322 \pm 12$ & $126 \pm 13$ & $F_{(1,2)}$ & $64.2^{*}$ & $F_{(2,15)}$ & 2.10 \\
\hline
\end{tabular}

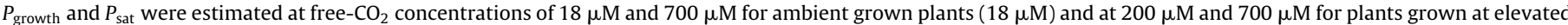

$\mathrm{CO}_{2}(200 \mu \mathrm{M})$, respectively, using non-linear regression of $\mathrm{CO}_{2}$ response curves. (Mean \pm S.E.), $n=5$. Level of significance.

${ }^{*} P<0.05$.

** $P<0.01$.

(Experiment 1), a nested analysis was used, in which the two replicate aquaria were nested in the $\mathrm{CO}_{2}$ treatment. Variance homogeneity was tested using Levene's test and data were logtransformed if necessary. Bonferroni's multiple range tests were used to identify significant differences between mean values at the $5 \%$ significance level. For pH drift experiments, one-way ANOVAs were performed for $\left[\mathrm{H}^{+}\right]$and mean values and confidence intervals were subsequently converted to $\mathrm{pH}$ values. Non-linear regression was used to fit all $\mathrm{CO}_{2}$ response curves individually with the following equation (SigmaPlot, Version 10.0, Systat Software, Inc.):

$\left[y=y_{0}+a\left(1-e^{-b x}\right)\right]$

The regression curves were subsequently used to estimate photosynthetic rates at ambient $\mathrm{CO}_{2}$ concentrations $(18 \mu \mathrm{M}$ in water and $385 \mu \mathrm{mol} \mathrm{mol}^{-1}$ in air) and saturating $\mathrm{CO}_{2}$ concentrations ( $700 \mu \mathrm{M}$ in water and $700 \mu \mathrm{mol} \mathrm{mol}^{-1}$ in air), plus at $200 \mu \mathrm{M}$ in water corresponding to the high $\mathrm{CO}_{2}$ treatment in Experiment 1. A photosynthetic quotient of $1.0(\mathrm{~mol} / \mathrm{mol})$ was used when comparing photosynthetic rates for aerial and submerged leaves which were measured from $\mathrm{CO}_{2}$ uptake and $\mathrm{O}_{2}$ production, respectively.

\section{Results}

\subsection{Experiment 1: acclimation potential of submerged leaves to different $\mathrm{CO}_{2}$ concentrations}

The submerged leaves of $L$. natans acclimated to high concentrations of free- $\mathrm{CO}_{2}$ by down-regulation of photosynthesis. The saturated photosynthetic rates at high $\left[\mathrm{CO}_{2}\right]$ were less than half the rates of plants acclimated to low $\left[\mathrm{CO}_{2}\right]$ (Table 1$)\left(P_{\text {sat }}\right.$ : measured at $700 \mu \mathrm{M}$ free- $\left.\left[\mathrm{CO}_{2}\right]\right)$. Photosynthesis at growth $\left[\mathrm{CO}_{2}\right], P_{\text {growth }}$ was slightly lower for plants grown at high $\left[\mathrm{CO}_{2}\right]$ than at low $\left[\mathrm{CO}_{2}\right]$ ( $P_{\text {growth }}$ : measured at $200 \mu \mathrm{M}$ free- $\left[\mathrm{CO}_{2}\right]$ for plants grown at high $\left[\mathrm{CO}_{2}\right]$ and at $18 \mu \mathrm{M}$ free- $\left[\mathrm{CO}_{2}\right]$ for plants grown at low $\left.\left[\mathrm{CO}_{2}\right]\right)$. For the plants grown at high $\left[\mathrm{CO}_{2}\right]$ the ratio of $P_{\text {growth }}$ to $P_{\text {sat }}$ was 0.62 compared to 0.33 for plants grown at low $\left[\mathrm{CO}_{2}\right]$. The activity of total Rubisco at high $\left[\mathrm{CO}_{2}\right]$ was approximately $40 \%$ of the activity at low $\left[\mathrm{CO}_{2}\right]$, but the activation states of Rubisco were similar (49-53\%) in the two treatments. The dry matter content was more than two times higher in the plants grown at high $\left[\mathrm{CO}_{2}\right]$ (Table 1 ), but the weight-specific $\mathrm{Chl}$ concentration at high $\left[\mathrm{CO}_{2}\right]$ was less than $43 \%$ of that at low $\left[\mathrm{CO}_{2}\right]$.

The capacity to utilize bicarbonate was reduced in plants grown at high $\left[\mathrm{CO}_{2}\right]\left(F_{2,22}=107.56, P<0.001\right)$. In the $\mathrm{pH}$ drift experiment the final $\mathrm{pH}$ reached 9.87 (9.67-10.24) for low $\left[\mathrm{CO}_{2}\right]$ grown plants, and only 9.51 (9.43-9.60) for plants grown at high $\left[\mathrm{CO}_{2}\right]$ (mean values and 95\% confidence intervals, $n=10)$. Controls without plant material reached $8.90(8.80-9.03)$ $(n=5)$.

\subsection{Experiment 2: inorganic carbon assimilation by different leaf types}

The submerged, floating and aerial leaf types of $L$. natans showed several adaptations towards maximising photosynthesis in water or air, respectively. The rates of photosynthesis measured in air differed significantly between the leaf types and were highest in aerial leaves and lowest in submerged leaves with rates in free-floating leaves in between and more variable (Fig. 1, Table 2). Ambient

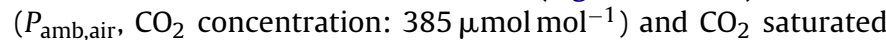
$\left(P_{\text {sat,air }}, \mathrm{CO}_{2}\right.$ concentration: $\left.700 \mu \mathrm{mol} \mathrm{mol}^{-1}\right)$ rates of photosynthesis in air of submerged leaves were only $1.0 \%$ and $6.6 \%$, respectively, of the mean rates in aerial leaves. The initial slope of the $\mathrm{CO}_{2}$ response curve, which can be interpreted as a measure of carbon affinity, differed between the leaf types, and was highest for aerial leaves and lowest for submerged leaves (Fig. 1). In water at ambient $\left[\mathrm{CO}_{2}\right]\left(18 \mu \mathrm{M}, P_{\mathrm{amb}, w a t e r}\right)$ the three leaf types had similar and low rates of photosynthesis, but at $700 \mu \mathrm{M}\left[\mathrm{CO}_{2}\right]\left(P_{\text {sat,water }}\right)$ the leaf types differed with highest rates in floating leaves and lowest rates in aerial leaves (Table 2). The $\mathrm{CO}_{2}$ response curves also showed no difference between leaf types at low $\left[\mathrm{CO}_{2}\right]$, but the response curves diverged at higher $\left[\mathrm{CO}_{2}\right]$ with highest rates in floating leaves and lowest rates in aerial leaves (Fig. 2).

The activities of Rubisco (Rubisco ${ }_{\text {Non }}$ ) were similar for submerged and aerial leaves, while the activities of the total Rubisco (Rubisco $_{\text {Max }}$ ) were significantly higher in aerial leaves compared

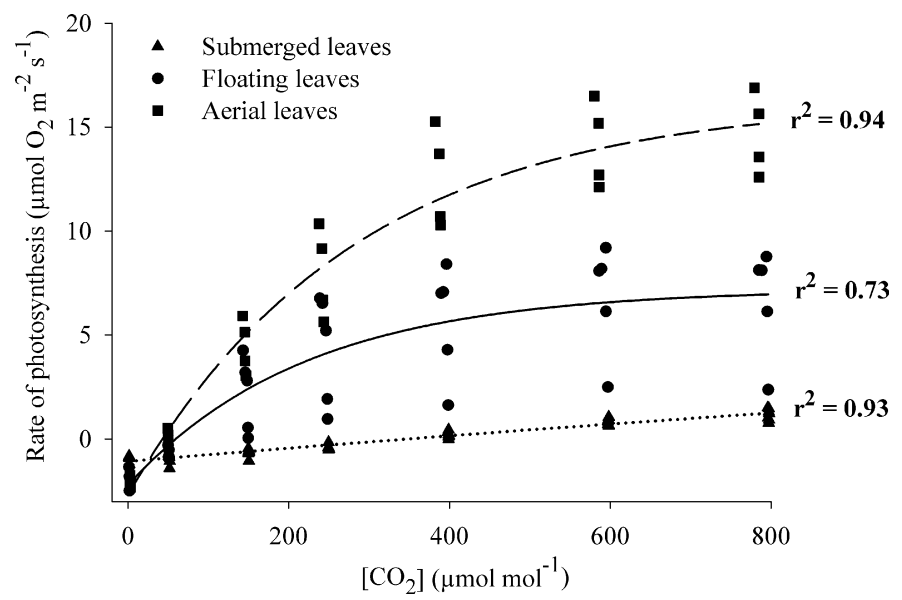

Fig. 1. $\mathrm{CO}_{2}$ response curves in air for the three leaf types of $L$. natans, showing all data points. Non-linear regression curves are fitted for each leaf type $\left[y=y_{0}+a\left(1-e^{-b x}\right)\right]$. $\left[\mathrm{CO}_{2}\right]$ is the external concentration of $\mathrm{CO}_{2}$ in the leaf chamber 
Table 2

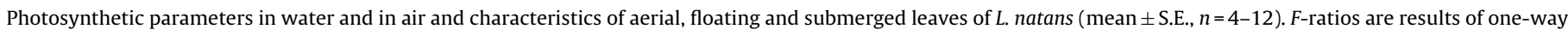
ANOVA.

\begin{tabular}{|c|c|c|c|c|c|}
\hline & Submerged & Floating & Aerial & Df & F-ratio \\
\hline \multicolumn{6}{|l|}{ Water } \\
\hline$P_{\text {amb,water }}\left(\mu \mathrm{mol} \mathrm{O}_{2} \mathrm{~m}^{-2} \mathrm{~s}^{-1}\right)$ & $0.48^{\mathrm{a}} \pm 0.03$ & $0.52^{\mathrm{a}} \pm 0.03$ & $0.50^{\mathrm{a}} \pm 0.03$ & $F_{(2,13)}$ & 0.37 \\
\hline$P_{\text {sat,water }}\left(\mu \mathrm{mol} \mathrm{O}_{2} \mathrm{~m}^{-2} \mathrm{~s}^{-1}\right)$ & $2.09^{a} \pm 0.15$ & $2.86^{\mathrm{b}} \pm 0.16$ & $1.11^{\mathrm{c}} \pm 0.15$ & $F_{(2,13)}$ & $32.5^{* * *}$ \\
\hline \multicolumn{6}{|l|}{ Air } \\
\hline$P_{\mathrm{amb}, \mathrm{air}}\left(\mu \mathrm{mol} \mathrm{CO} \mathrm{m}^{-2} \mathrm{~s}^{-1}\right)$ & $0.11^{\mathrm{a}} \pm 0.69$ & $5.51^{\mathrm{b}} \pm 0.82$ & $11.46^{\mathrm{c}} \pm 0.92$ & $F_{(2,15)}$ & $49.5^{* * *}$ \\
\hline$P_{\text {sat,air }}\left(\mu \mathrm{mol} \mathrm{CO}_{2} \mathrm{~m}^{-2} \mathrm{~s}^{-1}\right)$ & $0.98^{\mathrm{a}} \pm 0.69$ & $6.83^{\mathrm{b}} \pm 0.81$ & $14.75^{\mathrm{c}} \pm 0.91$ & $F_{(2,15)}$ & $73.9^{* * *}$ \\
\hline $\mathrm{Chl}_{a+b}\left(\mathrm{mg} \mathrm{g}^{-1} \mathrm{DW}\right)$ & $12.2^{\mathrm{a}} \pm 0.5$ & $12.2^{\mathrm{a}} \pm 0.5$ & $20.4^{\mathrm{b}} \pm 0.5$ & $F_{(2,31)}$ & $84.5^{* * *}$ \\
\hline Chl $a: b$-ratio & $2.12^{\mathrm{a}} \pm 0.07$ & $2.68^{\mathrm{b}} \pm 0.07$ & $3.01^{\mathrm{c}} \pm 0.07$ & $F_{(2,31)}$ & $41.8^{* * *}$ \\
\hline DW:FW-ratio & $0.067^{\mathrm{a}} \pm 0.006$ & $0.081^{\mathrm{a}} \pm 0.006$ & $0.106^{\mathrm{b}} \pm 0.006$ & $F_{(2,13)}$ & $11.9^{* *}$ \\
\hline $\operatorname{SLA}\left(\mathrm{m}^{2} \mathrm{~kg}^{-1} \mathrm{DW}\right)$ & $81^{a} \pm 3$ & $59^{b} \pm 3$ & $51^{b} \pm 3$ & $F_{(2,29)}$ & $21.4^{* * *}$ \\
\hline 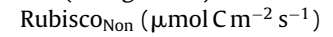 & $0.50^{\mathrm{a}} \pm 0.05$ & - & $0.43^{\mathrm{a}} \pm 0.05$ & $F_{(1,8)}$ & 0.96 \\
\hline Rubisco $_{\text {Max }}\left(\mu \mathrm{molCm} \mathrm{m}^{-2} \mathrm{~s}^{-1}\right)$ & $1.5^{\mathrm{a}} \pm 0.1$ & - & $2.5^{\mathrm{b}} \pm 0.1$ & $F_{(1,8)}$ & $45.1^{* *}$ \\
\hline
\end{tabular}

to submerged leaves (Table 2). Hence, a difference in Rubisco activation state between the two leaf types was observed with $33 \%$ activation in the submerged leaves and only $17 \%$ activation in the aerial leaves.

The Chl concentration and the dry matter content were significantly higher in aerial leaves than in floating and submerged leaves (Table 2 ). The $\mathrm{Chl}$ concentration in aerial leaves was approximately $67 \%$ higher than in floating and submerged leaves. The ratio of Chl $a$ to $\mathrm{Chl} b$ differed significantly between the three leaf types, with aerial leaves having the highest ratio and the submerged leaves the lowest. Specific leaf area (SLA) was lower in floating and aerial leaves than in submerged leaves (Table 2).

The $\mathrm{pH}$ drift experiment showed that aerial and floating leaves were unable to utilize bicarbonate, as the final $\mathrm{pH}$ after $48 \mathrm{~h}$ of incubation in light remained below pH 9 (Table 3 ). For the submerged leaves the final $\mathrm{pH}$ was higher (mean $\mathrm{pH}=9.32$ ), but not high enough to indicate a significant bicarbonate uptake. We have, however, in earlier $\mathrm{pH}$ drift incubations shown $L$. natans to be an efficient bicarbonate user, as final $\mathrm{pH}$ reached $\sim 10.5$ (unpublished data). Also in Experiment 1 of this study, $\mathrm{pH}$ values well above 10 were reached for some of the plants grown at low $\left[\mathrm{CO}_{2}\right]$ conditions (mean $\mathrm{pH}$ 9.87).

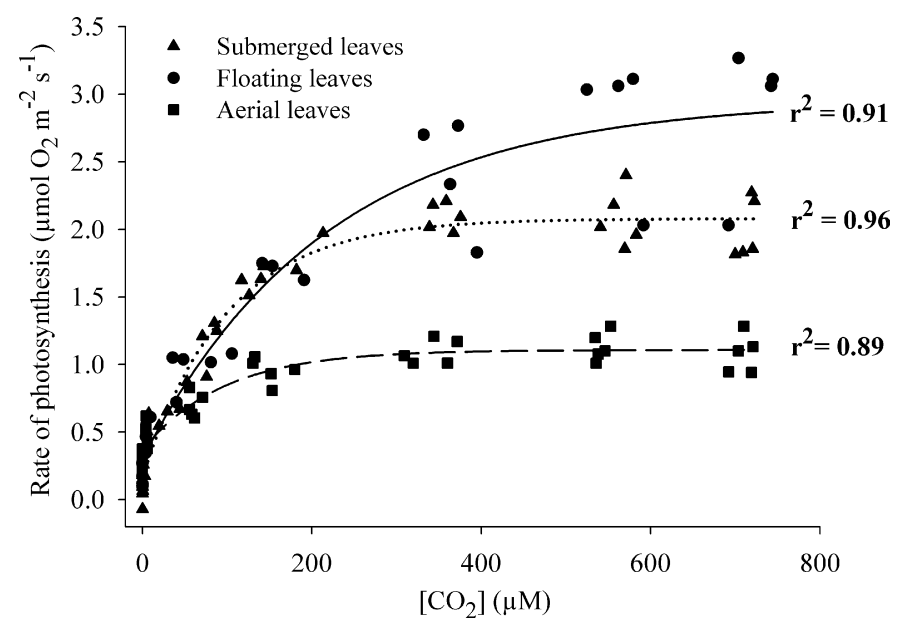

Fig. 2. $\mathrm{CO}_{2}$ response curves in water for the three leaf types of L. natans, showing all data points. Non-linear regression curves are fitted for each leaf type $\left[y=y_{0}+a\left(1-e^{-b x}\right)\right]$.

\section{Discussion}

\subsection{Acclimation potential of submerged leaves to different $\mathrm{CO}_{2}$ concentrations}

L. natans acclimated to the $\left[\mathrm{CO}_{2}\right]$ level in the growth medium and significant differences were observed in several photosynthetic parameters between plants grown at low and high $\left[\mathrm{CO}_{2}\right]$. The response pattern seen for $L$. natans is in accordance with earlier published results of plant responses to high $\left[\mathrm{CO}_{2}\right]$ (Madsen et al., 1996; Moore et al., 1999). The observed acclimation of submerged leaves to high $\left[\mathrm{CO}_{2}\right]$ can be interpreted as a down-regulation of the photosynthetic apparatus, as it resulted in both lower rates of photosynthesis, lower Chl contents and lower Rubisco activities. However, this response pattern to high $\left[\mathrm{CO}_{2}\right]$ is not universal, given that some submerged species keep the level of total Rubisco unaltered or even respond with an up-regulation of total Rubisco activity (Bowes, 1993). Also the response of terrestrial plants to elevated $\left[\mathrm{CO}_{2}\right]$ are reported to be species specific (Luo et al., 1999). For $L$. natans, the $\mathrm{CO}_{2}$ saturated photosynthetic rates of submerged leaves acclimated to high $\left[\mathrm{CO}_{2}\right]$ were in general less than half the rates of low $\left[\mathrm{CO}_{2}\right]$ acclimated leaves as a consequence of the downregulation of the photosynthetic system. But the photosynthetic rates measured at the growth conditions for low and high $\left[\mathrm{CO}_{2}\right]$ grown plants were comparable, indicating that plants acclimated to high $\left[\mathrm{CO}_{2}\right]$ by adjusting the photosynthetic apparatus to keep the rate of photosynthesis per dry weight constant. Judged from the ratio of $P_{\text {growth }}$ to $P_{\text {sat }}$, the plants grown at high $\left[\mathrm{CO}_{2}\right]$ used two thirds of the photosynthetic capacity at the prevailing growth conditions. In contrast, the low $\left[\mathrm{CO}_{2}\right]$ grown plants only used one third of the total capacity. A similar trend has been shown earlier for several other species of submerged macrophytes (Madsen and Sand-Jensen, 1991).

The higher photosynthetic rates of plants grown at ambient $\left[\mathrm{CO}_{2}\right]$ may partly have resulted from bicarbonate uptake contributing to the photosynthesis during the $\left[\mathrm{CO}_{2}\right]$ response measurements, as submerged leaves of $L$. natans were able to utilize bicarbonate. The ability to use bicarbonate is, however, plastic as a downregulation occurred in plants in the high $\left[\mathrm{CO}_{2}\right]$ treatment. This is a common and advantageous response for submerged plants, as $\mathrm{HCO}_{3}{ }^{-}$utilization is energy demanding (Sand-Jensen and Gordon, 1986). Thus, L. natans, as in many other submerged species, is able to effectively acclimate the photosynthetic apparatus to different levels of $\left[\mathrm{CO}_{2}\right]$, and does not seem to be restricted to growth in $\mathrm{CO}_{2}$ supersaturated waters. 
Table 3

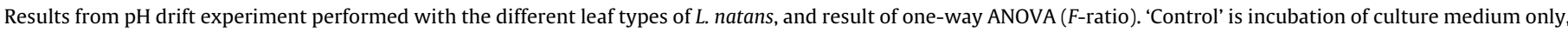
without plants. Final pH was measured after incubation in the light at $15^{\circ} \mathrm{C}$ for $48 \mathrm{~h}(n=5)$.

\begin{tabular}{|c|c|c|c|c|c|}
\hline & Submerged & Floating & Aerial & Control & F-ratio \\
\hline Final pH & $9.32^{\mathrm{a}}(9.13-9.68)$ & $8.86^{\mathrm{ab}}(8.72-9.07)$ & $8.75^{\mathrm{b}}(8.62-8.93)$ & $7.98^{\mathrm{c}}(7.92-8.05)$ & $213.00^{* * *}$ \\
\hline
\end{tabular}

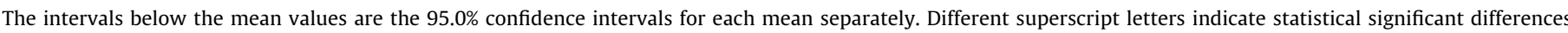
between mean values at the $5 \%$ significant level (post hoc, Bonferroni test, One-way ANOVA).

${ }^{* * *} P<0.001$.

\subsection{Inorganic carbon assimilation by different leaf types}

The leaf types of $L$. natans resembled submerged, floating and aerial leaves of other amphibious plant species in terms of morphology as well as Chl content, specific leaf area and dry matter contents (Bowes, 1987; Nielsen, 1993; Robe and Griffiths, 2000; Nielsen and Borum, 2008). The aerial leaves of L. natans had superior photosynthetic rates in air, which is in accordance with the general observation that aerial leaves consistently photosynthesise more efficient in air than submerged leaves in water at comparable conditions (Maberly and Spence, 1989; Madsen and Sand-Jensen, 1991; Madsen and Breinholt, 1995). The $\mathrm{CO}_{2}$-saturated rates of photosynthesis were more than ten-fold higher in air than in water and also ten times higher than the rates of photosynthesis of submerged leaves in air. These high photosynthetic rates are a consequence of the terrestrial characteristics of the aerial leaf type with thicker leaves and higher $\mathrm{Chl}$ densities compared to submerged leaves, and are in agreement with differences between aerial and submerged leaves found in other amphibious plants (Maberly and Spence, 1989; Nielsen, 1993). However, in contrast to earlier studies where the Rubisco activity in amphibious plants increased several-fold after emersion (Robe and Griffiths, 2000) we found that the activities of Rubisco were similar in aerial and submerged leaves (Table 2 ).

In contrast to submerged leaves, aerial leaves are usually not limited by $\mathrm{CO}_{2}$ availability, and it is therefore beneficial for aerial leaves to invest more in production of chlorophylls to optimize light capture. The chlorophyll concentration in the aerial leaves was significantly higher than the concentrations in both the floating and submerged leaves, and was at level with the highest values for emergent leaves of amphibious plants reported in the review of Nielsen (1993). This, and the apparent need for more structural tissue in aerial leaves, resulted in significantly higher amounts of dry matter in the aerial leaves than in the submerged leaves (Table 2). This places the aerial leaves of $L$. natans in-between true terrestrial and submerged leaves in terms of dry matter content, as the dry matter contents in these leaf types have been found to be $20 \%$ and 6.7\%, respectively (Van et al., 1976; Bowes, 1987). Plant parts exposed to the air also need to accumulate solutes in the cells to prevent loss of turgor pressure which as well increases the dry matter content (Robe and Griffiths, 2000).

It was not surprising that the aerial leaves performed poorly in water and had low rates of submerged photosynthesis (Fig. 2). The typical characteristics of aerial leaves, such as the presence of a thick cuticle, thick leaves and non-epidermal chloroplasts, are disadvantageous when in water. These characteristics of aerial leaves increase the diffusion resistance and lengthen the diffusion path of gasses from the media to the location of Rubisco, which in turn increase the $\mathrm{O}_{2}: \mathrm{CO}_{2}$-ratio at the site of carboxylation and increase photorespiration. Aerial leaves of $L$. natans have stomata on both sides of the leaf (personal observation) which ameliorate the $\mathrm{CO}_{2}$ availability in air and likely increase the affinity for $\mathrm{CO}_{2}$ in air as indicated by the higher initial slope of the $\mathrm{CO}_{2}$ response curve for aerial leaves (Fig. 1). When submerged, the stomata are blocked by water and the cuticle impedes uptake of $\mathrm{CO}_{2}$ which give rise to a low affinity for $\mathrm{CO}_{2}$ and thereby a lower initial slope of the $\mathrm{CO}_{2}$ response curve (Fig. 2). The submerged leaves of $L$. natans have no stomata (personal observation), and the $\mathrm{CO}_{2}$ must diffuse through the leaf surface to the site of carboxylation. This appeared to be inefficient in air, as submerged leaves had very low $\mathrm{CO}_{2}$ affinity in air (Fig. 1). The submerged leaves were expected to be the most efficient leaf type in water, because of the epidermal positioning of chloroplasts, the thin cuticle (not tested here) and the thinner leaves. However, the floating leaves had the highest rates of submerged photosynthesis, and the submerged and floating leaves had similar $\mathrm{CO}_{2}$ affinities (Fig. 1, Table 2). Additionally, the submerged leaves were shown to be able to take up bicarbonate (Table 3 ), but this uptake mechanism was apparently down-regulated under field conditions. The presence of floating and aerial leaves may also reduce the bicarbonate utilization of submerged leaves, as the emerged plant parts, which take up $\mathrm{CO}_{2}$ from the air, can be seen as an alternative strategy to enhance carbon gain (Bowes, 1987). Bicarbonate use has been documented in a few amphibious species before (Nielsen and Borum, 2008), but most amphibious plants are not bicarbonate-users (Bowes, 1987).

Floating leaves are expected to take up most of their inorganic carbon from the air (Madsen and Breinholt, 1995) through stomata on the upper side of the floating leaves. L. natans does have stomata on the upper side only of the floating leaves (personal observation) supporting this expectation, but the floating leaves actually appeared to be photosynthesising efficiently both in air and in water. Probably in field conditions the floating leaves are able to simultaneously take up $\mathrm{CO}_{2}$ from the atmosphere by the upper side of the leaf and $\mathrm{CO}_{2}$ from the water by the lower side of the leaf. This property might be beneficial to the plant, as it may provide some tolerance towards changing water regimes and efficient uptake of $\mathrm{CO}_{2}$ both when emerged and submerged. Furthermore, a rather high variability in $\mathrm{CO}_{2}$ uptake between the tested floating leaves was observed which could be caused by the anatomical-morphological transformations the leaves need to complete to adjust from a submerged to an aerial growth form. Hence, young floating leaves may still resemble submerged leaves and have lower photosynthetic rates in air compared to older more developed floating leaves.

The specific leaf areas of all three leaf types were higher than the average of earlier published values for amphibious plants (Nielsen, 1993). The relatively thin leaves of $L$. natans may provide an advantage, at least for the submerged leaves, as light is often greatly attenuated in water. In thin leaves the light harvesting complexes are dispersed over a large area which enhances light capture. Moreover, as the surface to volume ratio is high in thin leaves, the flux of ions and dissolved gasses to and from the leaf is maximised, and the inner path length to the chloroplasts is minimised, which is desirable, as gas diffusion often is the most limiting factor in submerged photosynthesis (Maberly and Madsen, 1998). The Chl $a$ :b-ratio was also clearly lower in the submerged leaves compared to aerial and floating leaves which may be an acclimation to the lower light availability in water than in air (Lichtenthaler, 1987). Despite this, the submerged leaves failed to show superior efficiency in photosynthesis in water, as mentioned earlier. When comparing the photosynthetic rates with those of other submerged amphibious species at similar $\mathrm{CO}_{2}$ availability $\left(100 \mu \mathrm{M} \mathrm{CO}_{2}\right)$, L. natans is placed 
just below the average (Madsen and Sand-Jensen, 1991; Nielsen, 1993). Part of the difference may be caused by temperature differences which in the present experiment was lower $\left(15^{\circ} \mathrm{C}\right.$ as opposed to $25^{\circ} \mathrm{C}$ for the values reported by Nielsen (1993)).

In conclusion, our study shows that $L$. natans exhibits significant plasticity in inorganic carbon uptake, which may help the species to survive as an amphibious plant. The production of floating leaves with efficient $\mathrm{CO}_{2}$ uptake from the air, and submerged leaves with the capacity to take up bicarbonate and further to respond effectively to changes in the level of free- $\mathrm{CO}_{2}$ in the water, are indeed advantageous properties of $L$. natans. Thus, the low competitive capacity of $L$. natans cannot be explained by inefficient photosynthesis and inability to acclimate properly to the prevailing conditions. Rather, the photosynthetic capacity and plasticity in carbon assimilation together with the amphibious growth form indicate a high capacity to acclimate to different and fluctuating environmental conditions. It therefore remains unexplained why $L$. natans has such a low competitive ability, although the somewhat low performance of submerged photosynthesis may be a contributing factor.

\section{Acknowledgements}

The study was financially supported by the Oticon Foundation (Scholarship) and the Danish Council for Independent Research Natural Sciences, Project no. 272-07-0633.

\section{References}

Allen, E.D., Spence, D.H.N., 1981. The differential ability of aquatic plants to utilize the inorganic carbon supply in fresh waters. New Phytol. 87, 269-283.

Bowes, G., 1987. Aquatic plant photosynthesis: strategies that enhance carbon gain. In: Crawford, R.M.M. (Ed.), Plant Life in Aquatic and Amphibious Habitats. Blackwell Scientific Publications, London, pp. 79-98.

Bowes, G., 1993. Facing the inevitable: plants and increasing atmospheric $\mathrm{CO}_{2}$. Annu. Rev. Plant Physiol. Plant Mol. Biol. 44, 309-332.

Greulich, S., Bornette, G., 1999. Competitive abilities and related strategies in four aquatic plant species from an intermediately disturbed habitat. Freshwater Biol. 41, 493-506

Greulich, S., Barrat-Segretain, M.-H., Bornette, G., 2001. Basal rosette or floating leaf canopy-an example of plasticity in a rare aquatic macrophyte. Hydrobiologia 448, 53-59.

Greulich, S., Bornette, G., Amoros, C., Roelofs, J.G.M., 2000a. Investigation on the fundamental niche of a rare species: an experiment on establishment of Luronium natans. Aquat. Bot. 66, 209-224.
Greulich, S., Bornette, G., Claude, A., 2000b. Persistence of a rare aquatic species along gradients of disturbance and sediment richness. J. Veg. Sci. 11, 415-424.

Lichtenthaler, H.K., 1987. Chlorophylls and carotenoids: pigments of photosynthetic biomembranes. Methods Enzymol. 148, 350-382.

Luo, Y., Reynolds, J., Wang, Y., Wolfe, D., 1999. A search for predictive understanding of plant responses to elevated $\left[\mathrm{CO}_{2}\right]$. Glob. Change Biol. 5, 143-156.

Maberly, S.C., Madsen, T.V., 1998. Affinity for $\mathrm{CO}_{2}$ in relation to the ability of freshwater macrophytes to use $\mathrm{HCO}_{3}{ }^{-}$. Funct. Ecol. 12, 99-106.

Maberly, S.C., Spence, D.H.N., 1989. Photosynthesis and photorespiration in freshwater organisms: amphibious plants. Aquat. Bot. 34, 267-286.

Madsen, T.V., Breinholt, M., 1995. Effects of air contact on growth, inorganic carbon sources, and nitrogen uptake by an amphibious freshwater macrophyte. Plant Physiol. 107, 149-154.

Madsen, T.V., Maberly, S.C., Bowes, G., 1996. Photosynthetic acclimation of submersed angiosperms to $\mathrm{CO}_{2}$ and $\mathrm{HCO}_{3}{ }^{-}$. Aquat. Bot. 53, 15-30.

Madsen, T.V., Sand-Jensen, K., 1991. Photosynthetic carbon assimilation in aquatic macrophytes. Aquat. Bot. 41, 5-40.

Moore, B.D., Cheng, S.H., Sims, D., Seemann, J.R., 1999. The biochemical and molecular basis for photosynthetic acclimation to elevated atmospheric $\mathrm{CO}_{2}$. Plant Cell Environ. 22, 567-582.

Nielsen, L.T., Borum, J., 2008. Why the free floating macrophyte Stratiotes aloides mainly grows in highly $\mathrm{CO}_{2}$-supersaturated waters. Aquat. Bot. 89, 379-384.

Nielsen, S.L., 1993. A comparison of aerial and submerged photosynthesis in some Danish amphibious plants. Aquat. Bot. 45, 27-40.

Nielsen, U.N., Riis, T., Brix, H., 2006a. The effect of weed cutting on Luronium natans. Aquat. Consv. Mar. Freshw. Ecosyst. 16, 409-417.

Nielsen, U.N., Riis, T., Brix, H., 2006b. The importance of vegetative and sexual dispersal of Luronium natans. Aquat. Bot. 84, 165-170.

Prins, H.B.A., Elzenga, J.T.M., 1989. Bicarbonate utilization: function and mechanism. Aquat. Bot. 34, 59-83.

Rebsdorf, A., Thyssen, N., Erlandsen, M., 1991. Regional and temporal variation in $\mathrm{pH}$, alkalinity and carbon dioxide in Danish streams, related to soil type and land use. Freshwater Biol. 25, 419-435.

Richards, C.L., Bossdorf, O., Muth, N.Z., Gurevitch, J., Pigliucci, M., 2006. Jack of all trades, master of some? On the role of phenotypic plasticity in plant invasions. Ecol. Lett. 9, 981-993.

Robe, W.E., Griffiths, H., 2000. Physiological and photosynthetic plasticity in the amphibious, freshwater plant, Littorella uniflora, during the transition from aquatic to dry terrestrial environments. Plant Cell Environ. 23, 1041-1054.

Sand-Jensen, K., Gordon, D.M., 1986. Variable $\mathrm{HCO}_{3}{ }^{-}$affinity of Elodea canadensis Michaux in response to different $\mathrm{HCO}_{3}{ }^{-}$and $\mathrm{CO}_{2}$ concentrations during growth. Oecologia 70, 426-432.

Smart, M.R., Barko, J.W., 1985. Laboratory culture of submersed freshwater macrophytes on natural sediments. Aquat. Bot. 21, 251-263.

Sultan, S.E., 2000. Phenotypic plasticity for plant development, function and life history. Trends Plant Sci. 5, 537-542.

Van, T.K., Haller, W.T., Bowes, G., 1976. Comparison of the photosynthetic characteristics of three submersed aquatic plants. Plant Physiol. 58, 761-768.

Willby, N.J., Eaton, J.W., 1993. The distribution, ecology and conservation of Luronium natans (L.) Raf. in Britain. J. Aquat. Plant Manage. 31, 70-76. 